\title{
PENGEMBANGAN PERANGKAT PEMBELAJARAN MATEMATIKA BERDASARKAN PEMBELAJARAN BERBASIS MASALAH UNTUK MENINGKATKAN KEMAMPUAN KOMUNIKASI MATEMATIS DAN SELF - EFFICACY SISWA
}

\author{
Sri Ramadhani ${ }^{1}$, Sahat Saragih ${ }^{2}$, Amin Fauzi $^{3}$
}

\begin{abstract}
ABSTRAK
Penelitian ini bertujuan untuk mendeskripsikan: 1) validitas perangkat pembelajaran berorientasi model pembelajaran berbasis masalah yang dikembangkan, 2) kepraktisan perangkat pembelajaran berorientasi model pembelajaran berbasis masalah yang dikembangkan, 3) keefektifan perangkat pembelajaran berorientasi model pembelajaran berbasis masalah yang dikembangkan, 4) peningkatan kemampuan komunikasi matematis siswa dengan menggunakan perangkat pembelajaran berorientasi model pembelajaran berbasis masalah yang dikembangkan, 5) peningkatan self-efficacy dengan menggunakan perangkat pembelajaran berorientasi model pembelajaran berbasis masalah yang dikembangkan, 6) mengidentifikasi proses jawaban siswa dengan menggunakan perangkat pembelajaran berbasis masalah yang telah dikembangkan. Penelitian ini merupakan penelitian pengembangan (research and development), produk yang dihasilkan adalah rencana pelaksanaan pembelajaran, lembar aktivitas siswa, buku petunjuk guru, dan buku siswa.Pengembangan perangkat pembelajaran berorientasi model pembelajaran berbasis masalah dikembangkan dengan menggunakan model pengembangan Four- $D$ dengan 4 tahap yaitu: define, design, develop dan disseminate. Subjek dalam penelitian ini adalah siswa kelas VIII-A dan VIII-B di SMP Islam Terpadu Nurul 'Azizi Medan. Dari hasil ujicoba I dan ujicoba II diperoleh:1) perangkat pembelajaran yang dikembangkan memenuhi kriteria valid, baik dalam validitas isi maupun validitas konstruk. 2) perangkat pembelajaran yang dikembangkan memenuhi kriteria praktis, 3) perangkat pembelajaran yang dikembangkan memenuhi criteria efektif, 4) terdapat peningkatan kemampuan komunikasi matematis siswa menggunakan perangkat pembelajaran yang dikembangkan, 5) terdapat peningkatan self-efficacy siswa menggunakan perangkat pembelajaran yang dikembangkan, 6) proses jawaban pada ujicoba II lebih banyak memperoleh kriteria penilaian "baik". Proses jawaban siswa pada ujicoba II lebih terstruktur, sistematis, serta sesuai dengan indikator kemampuan komunikasi matematis.
\end{abstract}

Kata Kunci: Model Pembelajaran, Pembelajaran Berbasis Masalah, Model Four-D Thiagarajan, Kemampuan Komunikasi Matematis, Self-Efficacy

\section{PENDAHULUAN}

Matematika sebagai salah satu disiplin ilmu yang mempunyai peranan penting dalam dunia pendidikan.Tujuan pembelajaran matematika yang dirumuskan oleh National Council of Teacher of Mathematics (2000) yaitu:(1) belajar untuk berkomunikasi (mathematical communication), (2) belajar untuk bernalar (mathematical reasoning), (3) belajar untuk memecahkan masalah (mathematical problem solving), (4) belajar untuk mengaitkan ide (mathematical connections), (5) pembentukan sikap positif terhadap matematika (positive attitudes toward mathematics).

\footnotetext{
${ }^{1}$ Corresponding: Sri Ramadhani

Program Magister Pendidikan Matematika Universitas Negeri Medan, Medan, 20221, Indonesia

E-mail : sri.ramadhani82@gmail.com

${ }^{2}$ Co-Author: Sahat Saragih \& Amin Fauzi

Program Studi Pendidikan Matematika, Universitas Negeri Medan, Medan, 20221, Indonesia
}

Salah satu aspek yang ditekankan dalam kurikulum KTSP dan NCTM adalah meningkatkan kemampuan komunikasi matematis siswa. Dalam proses belajar matematika kemampuan komunikasi matematis masih rendah. Hal senada juga dikemukakan Saragih (2007) yang menyatakan: "Kemampuan komunikasi dalam pembelajaran matematika perlu untuk diperhatikan, ini disebabkan komunikasi matematika dapat mengorganisasi dan mengkonsolidasi berpikir matematis siswa baik secara lisan maupun tulisan. Apabila siswa mempunyai kemampuan komunikasi tentunya akan membawa siswa kepada pemahaman matematika yang mendalam tentang konsep matematika yang dipelajari.

Berdasarkan hasil wawancara guru matematika SMP Islam Terpadu Nurul ‘Azizi Medan, ibu Citra Thamena M. Pd, siswa mengalami kesulitan untuk mengerjakannya materi teorema Pythagoras dalam bentuk soal cerita. Paling banyak siswa mengalami

Pengembangan Perangkat Pembelajaran Matematika Berdasarkan Pembelajaran Berbasis Masalah untuk Meningkatkan Kemampuan Komunikasi dan Self-Efficacy Siswa 
kesulitan dalam hal menafsirkan permasalahan dari soal-soal, mengalami kesulitan dalam hal mengekspresikan atau merepresentasikan masalah, situasi, ide kedalam model matematika atau gambar terlihat dari soal cerita yang diberikan pada siswa diberikan soal kemampuan komunikasi sebagai berikut:

Sebuah tangga yang panjangnya 2,5 meter bersandar pada dinding. Jika jarak ujung bawah tangga terhadap dinding adalah 1,5 meter, Berapakah tinggi ujung atas tangga dari lantai? Berikut salah satu contoh jawaban siswa:

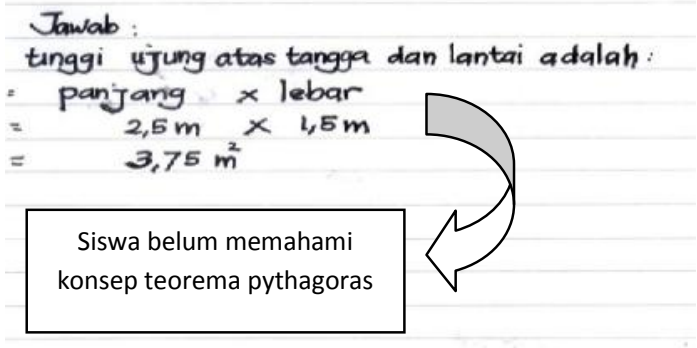

Gambar 1. Jawaban Siswa

Dari jawaban siswa dapat dilihat bahwa siswa masih mengalami kesulitan dalam memahami dan membuat model konseptual dari soal tersebut, siswa masih belum bisa merumuskan ide matematika ke dalam model matematika. Terdapat 16 siswa yang menjawab salah dengan jawaban yang tidak terdeskripsikan. Mereka tidak tahu permasalahan di atas pada dasarnya dapat diselesaikan dengan rumus pythagoras dan dapat digambarkan dalam bentuk segitiga siku-siku. Selanjutnya terdapat 8 siswa yang mampu menuliskan dalam model matematika, namun penggunaan rumus phytagoras masih salah dan terdapat 6 siswa yang tidak menjawab sama sekali.

Berdasarkan kasus ini peneliti menyimpulkan bahwa permasalahan yang terjadi saat ini adalah siswa masih belum mampu dalam mengkomunikasikan maksud dari soal yang diberikan. Hal ini dikarenakan pembelajaran selama ini hanya menjelaskan langkah-langkah untuk sekedar menghitung tanpa membantu siswa untuk mengemukakan ide/gagasan dalam wujud lisan dan tulisan. Selain itu, siswa masih selalu terfokus dengan angka-angka, sehingga ketika suatu permasalahan matematika disajikan berupa masalah dalam berbentuk simbol atau analisis yang mendalam maka siswa tidak mampu untuk menyelesaikannya. Maka dalam hal ini kemampuan komunikasi matematis siswa masih sangat perlu ditingkatkan, atau dengan kata lain kemampuan komunikasi matematis sungguh sangat dibutuhkan.

Hal ini diperkuat oleh hasil penelitian Kusmayadi (2010) yang menyatakan bahwa ada siswa yang mampu menyelesaikan suatu masalah matematika tetapi tidak mengerti apa yang dikerjakannya dan kurang memahami apa yang terkandung didalamnya. Selain itu, masih banyak siswa yang tidak mampu menyatakan benda nyata, gambar dan diagram ke dalam ide matematika, dan juga tidak mampu menyatakan peristiwa seharihari dalam bahasa atau simbol matematis.

Kesulitan yang dihadapi siswa antara lain menentukan informasi awal, mengubah bahasa sehari-hari pada soal menjadi bentuk matematika agar bisa diselesaikan. Dari ungkapan ini dapat diduga bahwa kemampuan komunikasi matematis siswa masih rendah. Selain kemampuan komunikasi matematis juga diperlukan sikap yang harus dimiliki oleh siswa, diantaranya adalah menghargai keindahan matematika, menyenangi matematika, memiliki keingintahuan yang tinggi dan senang belajar matematika. Guru harus menciptakan situasi belajar yang dapat melibatkan siswa aktif dan dapat meningkatkan minat siswa terhadap pembelajaran matematika sehingga diharapkan dapat menimbulkan sikap positif siswa terhadap belajar matematika, karena peran guru sebagai salah satu komponen pembelajaran sangat penting dalam keberhasilan pembelajaran.

Ada beberapa faktor matematika sulit dipelajari antara lain 1) kesulitan mengkomunikasikan ideide kedalam bahasa matematika pada saat diberikan soal- soal yang ada kaitannya dengan kehidupan sehari-hari; 2) Keyakinan siswa terhadap kemampuan yang dimilikinya dalam memberikan alasan-alasan, mengajukan pertanyaan dan menyelesaikan permasalahan matematika masih kurang; 3) siswa memandang matematika sebagai mata pelajaran yang membosankan, monoton, dan menakutkan.

Selain melihat pentingnya kemampuan komunikasi matematis siswa dalam pembelajaran, aspek lain yang menjadi permasalahan adalah kepercayaan diri (self efficacy) siswa. Bandura (1998:2) mendefenisikan self-efficacy sebagai keyakinan seseorang tentang kemampuan mereka untuk menghasilkan kinerja yang mempunyai pengaruh atas kehidupan mereka. Untuk mencapai tujuan di atas perlu adanya model pembelajaran yang tepat dan diharapkan mampu menyelesaikan permasalahan tersebut.

Model pembelajaran berbasis masalah, dapat meningkatkan partisipasi siswa dikelas secara aktif , meningkatkan rasa percaya diri serta dapat memunculkan kemampuan mengekspresikan diri siswa sehingga muncul self - efficacy siswa yang tinggi. Penerapan model pembelajaran ini 
diupayakan dapat menumbuhkembangkan kemampuan komunikasi matematis dan self efficacy siswa mulai bekerja dari permasalahan yang diberikan, mengaitkan masalah yang akan diselidiki dengan meninjau masalah itu dari banyak segi, melakukan penyelidikan autentik untuk mencari penyelesaian nyata terhadap masalah nyata, membuat produk berupa laporan, model fisik untuk didemonstrasikan kepada temanteman lain, bekerja sama satu sama lain untuk mengembangkan keterampilan sosial dan keterampilan berpikir.

Untuk mengukur kemampuan komunikasi matematis dan self - efficacy siswa, pada penelitian ini dikembangkan perangkat pembelajaran berbasis masalah pada materi teorema Pythagoras untuk siswa kelas VIII SMP, yang meliputi Rencana Pelaksanaan Pembelajaran (RPP), Buku Guru ( BG), Buku Siswa (BS), Lembar Aktivitas Siswa (LAS) dan soal tes kemampuan komunikasi matematis dan angket self-efficacy. Perangkat pembelajaran adalah segala bahan ajar yang disusun secara sistematis dan dipergunakan dalam kegiatan pembelajaran untuk menciptakan suasana belajar yang kondusif sehingga tujuan pembelajaran dapat tercapai.

Pengembangan perangkat pembelajaran menggunakan model 4-D yang terdiri dari Define, Design, Develop, dan Disseminate. Menurut Nieveen (2007:26) terdapat kriteria dalam menentukan kualitas hasil pengembangan peangkat pembelajaan yaitu (1) validity (valid); (2) practivally (praktis) dan (3) effectiveness (efektif).

\section{KAJIAN TEORITIS}

\subsection{Kemampun Komunikasi Matematis (Communication Mathematics)}

Istilah komunikasi berasal dari bahasa latin, yaitu communicatio yang berarti pemberitahuan atau pertukaran pikiran. Komunikasi matematis adalah kegiatan atau aktivitas seseorang dalam menyatakan suatu ide, konsep, gagasan matematika baik secara lisan maupun tulisan dalam bentuk simbol, gambar, data, grafik, atau tabel dengan orang lain.

Ramdani (2012:47) bahwa komunikasi matematis adalah kemampuan untuk berkomunikasi yang meliputi kegiatan penggunaan keahlian menulis, menyimak, menelaah, menginterpretasi kan, dan mengevaluasi. Dalam menyelesaikan suatu masalah yang terkait dengan komunikasi matematis siswa setidaknya harus memenuhi indikator-indikator kemampuan komunikasi matematis seperti dalam tabel 1 berikut:
Tabel 1. Indikator Kemampuan Komunikasi Matematis

\begin{tabular}{ll}
\hline NO & \multicolumn{1}{c}{ Indikator Kemampuan Komunikasi } \\
\hline 1. & $\begin{array}{l}\text { Kemampuan mengekspresikan ide-ide } \\
\text { matematis melalui lisan, tulisan, dan } \\
\text { mendemonstrasikannya serta menggambar } \\
\text { kannya secara visual. }\end{array}$ \\
\hline 2. & $\begin{array}{l}\text { Kemampuan memahami, meng interpretasi } \\
\text { kan, dan mengevaluasi ide-ide matematis } \\
\text { baik secara lisan, tulisan, maupun dalam } \\
\text { bentuk visual lainnya. }\end{array}$ \\
\hline 3. & $\begin{array}{l}\text { Kemampuan dalam menggunakan istilah } \\
\text { istilah, notasi-notasi matematika dan } \\
\text { struktur-strukturnya untuk menyajikan ide- } \\
\text { ide, meng gambarkan hubungan-hubungan } \\
\text { dengan model-model situasi. }\end{array}$ \\
\hline Kemampuan dalam penyelesaian masalah \\
matematika.
\end{tabular}

Selanjutnya penelitian yang dilakukan oleh Roland dan Patrick (2015) menemukan bahwa :

Through mathematical communication and discourse, teachers can foster student engage ment and paricipation while focusing on the deep conceptual understanding called for in the Common Core mathematics standards. This qualitative study focuses on the importance of students' mathematical communication (i.e. verbal and written) and discourse as they engage in problem solving, reasoning and proofs.

Penyataan tersebut mengandung makna komunikasi matematis baik lisan ataupun tulisan dalam pembelajaran sangat penting karena dapat menumbuhkan pemahaman konsep matematika pada siswa. Melalui komunikasi matematis, guru dapat menumbuhkan keterlibatan dan partisipasi siswa sehingga mereka terlibat pemecahan masalah, penalaran dan bukti sebagai syarat standar matematika.

Selanjutnya penelitian Laila, Charita dan Rhoda (2016) menemukan bahwa:

Challenging students to communicate both orally and in writing in mathematics class help deepen their conceptual understanding, improve mathematics performance and reduce anxiety towards mathematics. Results of the analysis revealed that the students exposed to mathematical communication approach have significantly higher achievement, conceptual understanding and significantly reduced anxiety compared to the Dynamic Learning Program (DLP) approach. Hence, mathematical communication is effective 
in improving students' achievement, conceptual understanding, and reducing anxiety.

Pernyataan tesebut mengandung makna bahwa merangsang siswa untuk berkomunikasi baik secara lisan maupun tulisan dalam pembelajaran matematika membantu memperdalam pemahaman konseptual mereka, meningkatkan aktivitas dalam pembelajaran matematika dan mengurangi kecemasan terhadap pembelajaran matematika. Hasil analisis menunjukkan bahwa siswa yang terbiasa dengan pendekatan komunikasi matematis memiliki prestasi yang jauh lebih tinggi, pemahaman konseptual dan kecemasan yang jauh berkurang dibandingkan dengan pendekatan Program Belajar Dinamis (DLP). Oleh karena itu, komunikasi matematis efektif dalam meningkatkan prestasi belajar siswa, pemahaman konseptual, dan mengurangi kecemasan.

\subsection{Kemampuan Self- efficacy}

Self - Efficacy terdiri dari kata "self" yang dapat diartikan sebagai unsur struktur kepribadian dan "Efficacy" yang maknanya penilaian diri. Self-efficacy adalah kepercayaan individu atas kemampuannya dalam menghadapi dan mengatur kehidupannya yang berkaitan dengan penilaian individu atas kecukupan, efisiensi, kompetensinya dalam menghadapi kehidupan sehari-hari. Bandura (1989:1175) mendefenisikan self-efficacy sebagai keyakinan orang tentang kemampuan mereka untuk menghasilkan tingkat kinerja yang ditunjuk bahwa latihan pengaruh atas peristiwa yang mempengaruhi kehidupan mereka.

Menurut Bandura ( Fauzi, 2007:4), Self Efficacy belief adalah keyakinan tentang kemampuan seseorang dalam belajar untuk menghasilkan sikap dan level yang ditunjukkan.

Selanjutnya hasil penelitian Ming-Jang, Chun ,dan Wei (2015:1-16) menemukan bahwa:

The influence of mathematics self-efficacy and diverse mathematical representations in learning materials on the performance and learning attitude of elementary school learners with regard to pattern reasoning. The research findings indicate that...(3) learners with high mathematics selfefficacy display more positive attitudes towards learning mathematics.

Hal tersebut mengandung makna pengaruh selfefficacy matematika dan representasi matematis dalam materi pembelajaran terhadap hasil dan sikap belajar peserta didik sekolah dasar berkenaan dengan pola penalaran. Temuan penelitian menunjukkan bahwa..... (3) peserta didik dengan self-efficacy matematika tinggi menunjukkan sikap positif terhadap pembelajaran matematika.

Selanjutnya penelitian yang dilakukan oleh Arup dan Aditi (2016:25-31) menyimpulkan bahwa "This indicates that a healthy attitude towards mathematics can nurture self efficacy among students". Hal tersebut mengandung makna sebuah studi korelasional mengungkapkan bahwa hubungan antara siswa Sekolah Menengah Atas terhadap pembelajaran matematika dan selfefficacy tinggi. Hal ini menunjukkan bahwa sikap baik terhadap matematika dapat memupuk kepercayaan diri di kalangan siswa tingkat SMA

\subsection{Model Pembelajaran Berbasis Masalah (Problem Basaed Learning)}

Model pembelajaran adalah suatu perencanaan atau suatu pola yang digunakan sebagai pedoman dalam merencanakan pembelajaran dikelas. Menurut B.Sinaga (2015) Model pembelajaran adalah suatu kerangka konseptual atau pola yang digunakan sebagai pedoman dalam merencanakan dan mewujudkan suatu proses pembelajaran di kelas yang mengarahkan kita dalam mendisain pembelajaran untuk membelajarkan peserta didik, sehingga tujuan pembelajaran tercapai.

Tabel 2. Sintaks Pengajaran

\begin{tabular}{|c|c|}
\hline Tahap & Tingkah Laku Guru \\
\hline Tahap - 1 & Guru menjelaskan tujuan \\
\hline $\begin{array}{l}\text { Orientasi siswa } \\
\text { pada masalah }\end{array}$ & $\begin{array}{l}\text { pembelajaran, menjelaskan } \\
\text { logistic yang dibutuhkan , } \\
\text { mengajukan fenomena atau } \\
\text { demonstrasi atau cerita untuk } \\
\text { memunculkan masalah, } \\
\text { memotivasi siswa untuk terlibat } \\
\text { dalam pemecahan masalah yang } \\
\text { dipilih. }\end{array}$ \\
\hline $\begin{array}{l}\text { Tahap - } 2 \\
\text { Mengorganisasi } \\
\text { siswa untuk } \\
\text { belajar }\end{array}$ & $\begin{array}{l}\text { Guru membantu siswa untuk } \\
\text { mendefenisikan dan meng } \\
\text { organisasi kan tugas belajar yang } \\
\text { berhubungan dengan masalah } \\
\text { tersebut. }\end{array}$ \\
\hline $\begin{array}{l}\text { Tahap - 3 } \\
\text { Membimbing } \\
\text { penyelidikan } \\
\text { individual } \\
\text { maupun } \\
\text { kelompok }\end{array}$ & $\begin{array}{l}\text { Guru mendorong siswa untuk } \\
\text { mengumpulkan informasi yang } \\
\text { sesuai, melaksanakan eksperimen, } \\
\text { untuk mendapatkan penjelasan } \\
\text { dan pemecahan masalah. }\end{array}$ \\
\hline $\begin{array}{l}\text { Tahap - } 4 \\
\text { Mengembang } \\
\text { kan dan menya } \\
\text { jikan hasil karya }\end{array}$ & $\begin{array}{l}\text { Guru membantu siswa dalam } \\
\text { merencanakan dan menyiapkan } \\
\text { karya yang sesuai seperti laporan, } \\
\text { video dan model serta membantu } \\
\text { mereka untuk berbagi tugas } \\
\text { dengan temannya. }\end{array}$ \\
\hline $\begin{array}{l}\text { Tahap - 5 } \\
\text { Menganalisis } \\
\text { dan meng } \\
\text { evaluasi proses } \\
\text { pemecahan }\end{array}$ & $\begin{array}{l}\text { Guru membantu siswa untuk } \\
\text { melakukan refleksi atau evaluasi } \\
\text { terhadap penyelidikan mereka dan } \\
\text { proses - proses yang mereka } \\
\text { gunakan. }\end{array}$ \\
\hline
\end{tabular}

masalah

Sumber : Ibrahim, dkk ( dalam Rusman, 2011:243)

Berikut ini merupakan beberapa hasil penelitian yang relevan dengan penelitian ini. 
Hasil penelitian Surya, Syahputra dan Juniarti (2018) yang berjudul Effect of Problem Based Learning Toward Mathematical Communication Ability and Self-Regulated Learning. Hasil penelitiannya menunjukkan bahwa: (1) Ada pengaruh yang signifikan antara model pembelajaran (PBL, konvensional) terhadap pembelajaran mandiri siswa, (2) Proses checkout menjawab siswa dalam menyelesaikan kemampuan komunikasi matematis menggunakan pembelajaran PBL lebih baik, sistematis dan terstruktur daripada pembelajaran konvensional. (3) Dari ketiga indikator kemamampuan komunikasi matematis diukur berdasarkan temuan lapangan untuk melihat bahwa ekspresi matematis indikator masih dianggap sulit dilakukan oleh siswa.

Syahputra dan Surya (2014:52) dalam penelitiannya yang berjudul The Development of Problem Based Learning Model to Construct High Order Thinking Skill Students' on Mathematical Learning in SMA/MA. Hasil penelitian tersebut menemukan bahwa buku guru dan buku siswa untuk kelas X SMA yang dikembangkan, fokus pada tahapan penyelesaian masalah matematika berorientasi pada pembelajaran berbasis masalah mampu meningkatkan kemampuan berpikir tingkat tinggi siswa. Hasil penelitian juga menunjukkan bahwa terdapat peningkatan secara signifikan kemampuan pemecahan masalah pada siswa.

Selanjutnya penelitian Surya dan Syahputra (2017:12) yang berjudul Improving High-Level Thinking Skills by Development of Learning PBL Approach on the Learning Mathematics for Senior High School Students, menemukan bahwa: bahan ajar yang dikembangkan berupa buku guru dan buku siswa fokus pada langkah penyelesaian masalah serta berorientasi pembelajaran berbasis masalah dapat meningkatkan kemampuan berpikir tingkat tinggi siswa. Hasil penelitian juga menunjukan bahwa terdapat peningkatan secara signifikan kemampuan siswa dalam memecahkan masalah di tiga kabupaten / kota di Sumatera Utara.

Selanjutnya penelitian Furaiza, Syahputra dan Rajagukguk (2018) yang berjudul Differences in Metacognition and Mathematical Communication Ability Between Students Taught Using Problem Based Learning Model and Numbered Head Together Cooperative Learning Modelat SMP Kartika I-2 Medan.

Salah satu hasil penelitiannya menunjukkan bahwa terdapat perbedaan kemampaun komunikasi matematis antara siswa yang mendapat Pembelajaran Berbasis Masalah dan yang mendapat pembelajaran kooperatif tipe Numbered Head Together. Rata-rata kemampuan komunikasi matematis siswa yang mendapat Pembelajaran
Berbasis Masalah lebih baik dari siswa yang mendapat model pembelajaran Kooperatif tipe Numbered Head Together.

Selanjutnya hasil penelitian Hasibuan dan Amry (2017:60) yang berjudul Differences Of Students Mathematical Communication Ability Between Problems Based Learning, Realistic Mathematical Education And Inquiri Learning In Smp Negeri 1 Labuhan Deli. Hasil penelitian menemukan bahwa ada perbedaan kemampuan komunikasi matematis antara siswa yang diberi pembelajaran problem based dengan siswa yang diberi pendidikan matematika realistis dan siswa yang diberi pembelajaran inquiry. Dalam kasus ini, rata-rata kemampuan komunikasi matematis menggunakan pembelajaran berbasis masalah lebih baik daripada pembelajaran matematika realistic dan pembelajaran inquiry.

Penelitian yang dilakukan Mustafa, Sinaga dan Asmin (2017) yang berjudul Development of Learning Devices Through Problem Based Learning Model to Improve Students Metacognition Ability in SMPN 17 Medan. Hasil peneitian tersebut menemukan bahwa: (1) perangkat pembelajaran berorientasi pembelajaran berbasis masalah yang dikembangkan memenuhi kriteria valid, praktis dan efektif, (2) perangkat pembelajaran berorientasi model pembelajaran berbasis masalah yang dikembangkan dapat meningkatkan kemampuan metakognisi siswa hingga kriteria sedang.

Dalam penelitian yang dilakukan oleh Fatokun (2013:215) dengan judul A Problem Based Learning (PBL) Application for the Teaching of Mathematics and Chemistry in Higher Schools and Tertiary Education. Hasil penelitiannya menekankan bahwa tidak ada model tunggal pada suatu permasalahan dan berbagai pendekatan yang memungkinkan untuk mendapatkan suatu pembelajaran yang baik. Hanya, salah satu pendekatan yang menurut penelitian yang telah dilakukan, efektif digunakan untuk meningkatkan kemampuan siswa dalam pembelajaran matematika dan kimia adalah penerapan pendekatan pembelajaran berbasis masalah (PBM).

Selanjutnya penelitian yang dilakukan oleh Padmavathy dan Mareesh (2013) dalam penelitiannya yang berjudul Effectiveness of Problem Based Learning In Mathematics. Dalam penelitian ini, peneliti membuat upaya untuk menguji efektivitas pembelajaran berbasis masalah dalam mengajar konsep matematika di tingkat sekolah menengah. Sampel antara kelas eksperimen dan kelas kontrol terdiri dari jumlah yang sama (30). Data yang dikumpulkan dengan menggunakan alat yang tepat dan dianalisis menggunakan rata-rata, standar deviasi and uji t. Temuan dari penelitian ini menunjukkan bahwa 
pembelajaran berbasis masalah memiliki pengaruh dalam mengajar matematika dan meningkatkan pemahaman siswa, serta kemampuan untuk menggunakan konsep dalam kehidupan nyata.

Penelitian selanjutnya yang dilakukan oleh Gabriel, Luminita, Sorin, Ana, dan Laura (2014) menemukan bahwa:

In this sense, problem-based learning (PBL) often known as inquiry-based learning - represents an effective way of working with students who may thus be helped to build basic skills in various domains or curricular areas. Generally, the method involves a central question (problem), proposed and explained by the teacher, with the students working cooperatively and deciding for the proper strategy with the view to solve the problem. The feedback collected from teachers and students was positive, with important achievements in students' understanding of Science concepts, but also in taking owner ship of their learning.

Pernyataan tesebut mengandung makna bahwa dalam penelitian ini problem based learning (PBL) merupakan model pembelajaran yang efektif bagi siswa yang membutuh kan karena dapat membantu membangun kemampuan dasar dalam kegiatan pembelajaran. Model ini melibatkan pertanyaan (masalah) yang diajukan oleh guru sebagai tugas siswa dengan cara kerjasama dalam bentuk kelompok untuk menemukan konsep dan memecahkan masalah matematika. Karakteristik PBM terdiri dari : mengorientasikan siswa pada masalah nyata, mengorganisasi siswa untuk belajar, membimbing penyelidikan individu dan kelompok, mengembangkan dan menyajikan hasil karya dan menganalisa dan mengevaluasi proses pemecahan masalah

Dari beberapa penelitian yang telah dilakukan dapat disimpulkan bahwa memilki komunikasi matematis dan self-efficacy yang baik mempengaruhi hasil belajar matematika yang baik pula. Apalagi didukung dengan model pembelajaran berbasis masalah yang dilakukan dalam bentuk kelompok. Sehingga dalam pembelajaran siswa dapat menemukan konsep dasar pembelajaran matematika.

\section{METODE PENELITIAN}

\subsection{Tempat dan Waktu Penelitian}

Penelitian ini dikategorikan ke dalam jenis penelitian pengembangan (development research) dengan menggunakan model pengembangan perangkat pembelajaran Thiagarajan 4-D. Dalam penelitian ini yang dikembangkan adalah perangkat pembelajaran berdasarkan pembelajaran berbasis masalah yang meliputi buku guru ( BG), buku siswa (BS), lembar aktivitas siswa (LAS), rencana pelaksanaan pembelajaran ( RPP ), tes kemampuan komunikasi matematis, dan angket Self-efficacy. Penelitian ini dilaksanakan di SMP Islam Terpadu Nurul 'Azizi Medan pada semester genap Tahun Ajaran 2017/2018 di kelas VIII. Penelitian ini dilaksanakan sebanyak 5 (lima) pertemuan untuk satu kali uji coba. Sedangkan objek dalam penelitian ini adalah perangkat pembelajaran berdasarkan pembelajaran berbasis masalah pada materi teorema Pythagoras.

Penelitian ini dibagi dalam dua tahap, tahap pertama adalah pengembangan perangkat pembelajaran. Pengembangan perangkat pembelajaran yang meliputi: (1) validitas Buku Guru ;(2) validitas Buku Siswa; (3) validitas LAS; (4) validitas instrumen tes kemampuan Komunikasi Matematis. Tahap kedua adalah implementasi perangkat pembelajaran yang sudah divalidasi untuk melihat kepraktisan dan keefektifannya.

Model pengembangan yang digunakan untuk mengembangkan perangkat pembelajaran dalam penelitian ini adalah modifikasi dari model Thiagarajan, Semmel dan Semmel yang dikenal dengan model 4-D (Four D Mode) yang terdiri dari 4 tahap pengembangan yaitu tahap pendefinisian (define), perancangan (design), pengembangan (develop) dan penyebaran (disseminate) (Trianto, 2007:56).

Tabel 3. Rancangan Penelitian One Shot Case Study

\begin{tabular}{cc}
\hline Treatment & Posttest \\
\hline X & O \\
\hline & (Sumber, Sugiyono, 2010:74)
\end{tabular}

Keterangan:

$\mathrm{X}$ : Treatment dengan perangkat pembelajaran menggunakan pembelajaran berbasis masalah yang dikembangkan.

$\mathrm{O}$ : Posttest kemampuan komunikasi matematis

\section{HASIL PENELITIAN}

\subsection{Tahap I Pendefinisian (Define)}

Pada tahap pendefinisian, dilaksanakan lima analisis, yaitu (1) Analisis awal akhir; (2) Analisis siswa; (3) Analisis konsep;(4) Analisis tugas; (5) Perumusan tujuan pembelajaran. Hasil dari setiap kegiatan pada tahap pendefinisian (define) diuraikan sebagai berikut.

1) Analisis Awal - Akhir (Front-End Analysis)

Berdasarkan hasil observasi terhadap perangkat pembelajaran di SMP Islam Terpadu Nurul 'Azizi Medan ditemukan beberapa kelemahan pada perangkat pembelajaran yang digunakan guru yang secara tidak langsung memberikan konstribusi terhadap rendahnya kemampuan komunikasi matematis dan self-efficacy siswa. Guru belum mengembangkan perangkat pembelajaran yang memenuhi kriteria yang baik yaitu valid, praktis dan efektif. Perangkat pembelajaran yang 
digunakan oleh guru dan siswa hanya berdasarkan buku teks yang umum, dimana menghasilkan suatu pembelajaran yang berpusat pada guru sehingga siswa tidak aktif dalam pembelajaran.

Ditinjau dari buku siswa (BS) yang digunakan di sekolah SMP Islam Terpadu Nurul 'Azizi Medan sebagian besar masih bersifat umum, tidak diawali dengan masalah tetapi dimulai dengan konsep sehingga siswa tidak mengkonstruk sendiri pengetahuannya dan tidak menemukan sendiri konsepnya. Kemudian penyajian materi pada buku siswa (BS) tersusun dari: 1) definisi (pengertian konsep); 2) contoh soal; dan 3) latihan soal. Dimana kegiatan awal pada buku teks matematika diawali dengan menjelaskan pengertian (definisi) suatu konsep dalam matematika. Kemudian, memberikan contoh penerapan konsep tersebut, dan diakhiri dengan memberikan soal latihan. Kemudian buku siswa (BS) tidak memuat soal-soal kontekstual yang berhubungan dengan kehidupan sehari - hari yang nyata dialami di lingkungan siswa serta penyajian soal-soal masih kurang dalam mendukung pengembangan kemampuan komunikasi matematis.

Berhubungan dengan LAS, LAS belum dimanfaatkan di SMP Islam Terpadu Nurul 'Azizi Medan, sehingga menyebabkan siswa kurang terlatih dalam mengasah kemampuan-kemampuan matematika. Demikian pula dengan alat evaluasinya. Guru merancang alat evaluasi tanpa memperhatikan indikator- indikator kemampuan yang ingin dicapai.

Lebih lanjut, fakta di lapangan menunjukkan bahwa guru matematika di sekolah sebagai praktisi pendidikan, melaksanakan pembelajaran di kelas dengan menerapkan model-model pembelajaran yang kurang relevan dengan karakteristik dan tujuan pembelajaran matematika. Kondisi implementasi pembelajaran matematika yang ada atau sedang berjalan di sekolah belum menerapkan pembelajaran kontekstual dimana guru harusnya mengaitkan antara materi pembelajaran yang dipelajari dengan kondisi/situasi kehidupan nyata dan mengaitkan antara materi matematika dengan budaya lokal. Sehingga pengalaman belajar yang siswa dapatkan di kelas akan membantu siswa belajar aktif dalam merekonstruksi pengetahuan matematika melalui pemecahan masalah yang bersumber dari fakta dan lingkungan budaya.

Dari pembahasan di atas, telah dijabarkan beberapa masalah utama yang terdapat dalam proses pembelajaran matematika di SMP Islam Terpadu Nurul 'Azizi Medan. Masalah ini berupa rendahnya kualitas perangkat pembelajaran yang digunakan di SMP Islam Terpadu Nurul 'Azizi Medan yang berdampak pada rendahnya kemampuan komunikasi matematis dan selfefficacy siswa. Untuk mengatasi masalah tersebut, perlu dikembangkan perangkat pembelajaran yang memenuhi kriteria valid, praktis dan efektif yang penerapannya akan berdampak pada peningkatan kemampuan komunikasi matematis dan selfefficacy siswa SMP Islam Terpadu Nurul 'Azizi Medan.

Pada hakikatnya, pengembangan perangkat pembelajaran baik itu buku guru, buku siswa, RPP maupun LAS harus mengacu pada suatu model pembelajaran agar perangkat pembelajaran yang dikembangkan menjadi satu kesatuan yang saling melengkapi dan terfokus pada tujuan yang ingin dicapai. Salah satu model pembelajaran yang menekankan pada aspek kognitif siswa dan mengutamakan keaktifan siswa adalah pembelajaran berbasis masalah .

Dengan perangkat pembelajaran berdasarkan pembelajaran berbasis masalah ini, diupayakan dapat mengembangkan kemampuan komunikasi matematis siswa dimana siswa mulai mengkonstruk pengetahuan dari permasalahan nyata yang diberikan, menemukan penyelesaian dengan mengaitkan masalah yang akan diselidiki dengan meninjau masalah itu dari banyak segi, melakukan penyelidikan autentik dengan bertanya melalui belajar berkelompok untuk mencari penyelesaian nyata terhadap masalah nyata, membuat prosedur berupa laporan untuk didemonstrasikan kepada teman-teman lain, bekerja sama satu sama lain untuk mengembangkan self-efficacy dan keterampilan berpikir. Dengan demikian, maka pembelajaran akan berpusat kepada siswa

\section{2) Analisis Siswa (Learner Analysis)}

Pada tahap ini, analisis yang dilakukan terhadap siswa SMP Islam Terpadu Nurul 'Azizi Medan yaitu dari segi karakteristik siswa yang meliputi perkembangan kognitif, kemampuan akademik dan latar belakang sosial ekonomi siswa. Secara umum, perkembangan kognitif siswa SMP Islam Terpadu Nurul 'Azizi Medan memasuki tahap operasional formal. Hal ini ditandai dari usia siswa SMP Islam Terpadu Nurul 'Azizi Medan yaitu berada pada rentang usia 12-14 tahun, yang jika dirujuk pada pendapat Piaget (Trianto, 2009:30), maka perkembangan kognitif siswa pada usia tersebut adalah tahap operasional formal. Perkembangan kognitif pada tahap ini ditandai dengan cara berpikir yang lebih logis, abstrak dan idealistik. Oleh karena itu, sangat tepat jika pembelajaran matematika diawali dengan benda konkret atau abstrak yang dekat dengan kehidupan mereka, sehingga diharapkan dapat membantu meningkatkan kemampuan-kemampuan matematika siswa khususnya kemampuan komunikasi matematis dan self-efficacy siswa.

Selanjutnya, hasil analisis kemampuan akademik siswa SMP Islam Terpadu Nurul 'Azizi 
Medan tergolong rendah. Hal ini berdasarkan hasil wawancara langsung dengan salah satu guru matematika SMP Islam Terpadu Nurul 'Azizi Medan, Ibu Citra Thamena yang mengatakan bahwa hasil ujian akhir siswa kelas VIII semester ganjil hampir 50\% tidak mencapai KKM $(\geq 75)$, selanjutnya proses pembelajaran yang dilakukan selama ini diawali dengan menjelaskan konsep atau prosedur dengan sedikit tanya jawab, memberi contoh soal dan ditutup dengan pemberian soal latihan yang serupa dengan contoh soal. Selain itu, pengaturan siswa untuk belajar secara berkelompok jarang dilakukan. Iklim pembelajaran seperti ini yang membuat siswa menjadi bosan dan kurang tertarik dalam mengikuti pembelajaran matematika, sehingga hal ini akan mempengaruhi hasil belajarnya yang mengakibatkan siswa tidak terbiasa mengkonstruk pengetahuan atau cara penyelesaian sendiri dan kurang aktif dalam pembelajaran yang berdampak pada rendahnya kemampuan komunikasi matematis.

Selain kemampuan komunikasi matematis, selfefficacy siswa SMP Islam Terpadu Nurul 'Azizi Medan juga tergolong rendah. Hal ini disimpulkan dari hasil wawancara dengan ibu Citra Thamena selaku guru mata pelajaran matematika di kelas VIII SMP Islam Terpadu Nurul 'Azizi Medan.

Jika dilihat dari latar belakang sosial ekonomi, secara umum pekerjaan orang tua siswa di SMP Islam Terpadu Nurul 'Azizi Medan adalah PNS. Secara keseluruhan sosial ekonomi orang tua siswa berada pada kategori menengah ke atas. Hasil ini diperoleh melalui wawancara dengan guru matematika yang sekaligus bertindak sebagai wali kelas yang mengetahui Gambaran secara umum masing-masing siswanya.

\section{3) Analisis Konsep}

Materi pelajaran yang digunakan dalam penelitian ini adalah materi teorema pythagoras untuk SMP kelas VIII dengan mengacu pada Kurikulum KTSP. Analisis konsep ini ditujukan untuk mengidentifikasi, merinci, dan menyusun secara sistematis konsep-konsep yang akan dipelajari siswa pada materi teorema pythagoras menjadi sebuah peta konsep. Peta konsep ini kemudian disesuaikan dengan pembelajaran berbasis masalah. Peta konsep yang dihasilkan kemudian dicantumkan pada Buku Siswa (BS). Secara keseluruhan peta konsep yang dihasilkan dalam penelitian ini adalah sebagai berikut:

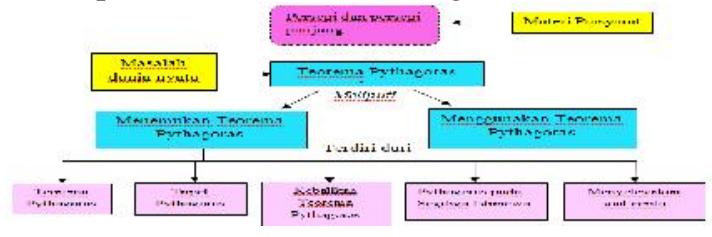

Gambar 3. Hasil Analisis Konsep untuk Materi Teorema Pythagoras

\section{4) Analisis Tugas}

Hasil analisis tugas yang diperoleh mengacu pada analisis konsep. Analisis tugas ini disusun berdasarkan standar kompetensi dan kompetensi dasar yang mengacu pada kurikulum KTSP mengenai materi teorema Pythagoras .Selanjutnya, hasil analisis tugas yang merujuk pada Kompetensi Dasar (KD).

Tugas yang dilakukan oleh siswa dalam pembelajaran yang terdapat di LAS adalah menemukan konsep atau pengetahuan, menerapkan konsep/pengetahuan yang ditemukan tersebut untuk menyelesaikan masalah dalam kehidupan sehari-hari.

\section{5). Spesifikasi tujuan pembelajaran}

Spesifikasi tujuan pembelajaran merupakan acuan dalam merancang perangkat pembelajaran dengan pembelajaran berbasis masalah. Kegiatan pada langkah ini adalah melakukan penjabaran indikator pencapaian hasil belajar kedalam indikator yang lebih spesifik yang disesuaikan dengan hasil analisis materi dan analisis tugas yang dilakukan sebelumnya. Indikator/tujuan pembelajaran disesuaikan dengan standar kompetensi dan kompetensi dasar dalam kurikulum KTSP.

\subsection{Tahap II Perancangan (Design)}

Tujuan dari tahap ini adalah merancang perangkat pembelajaran sehingga diperoleh draft (contoh perangkat pembelajaran) untuk materi Teorema Pythagoras berdasarkan pembelajaran berbasis masalah. Pada tahap perancangan dilaksanakan empat tahapan yaitu (1) Penyusunan tes dan non tes; (2) Pemilihan media; (3) Pemilihan format; dan (4) Perancangan awal.

\section{1) Hasil Penyusunan Tes dan Non Tes}

Tes dan non-tes disusun berdasarkan spesifikasi tujuan pembelajaran dan indikator kemampuan yang diukur. Tes yang disusun adalah tes kemampuan komunikasi matematis, dan nontes yang disusun adalah angket kemandirian belajar.

a. Tes kemampuan komunikasi matematis

Setelah tes disusun berdasarkan spesifikasi tujuan pembelajaran dan indikator kemampuan yang diukur, kemudian selanjutnya disusun kisikisi tes kemampuan komunikasi matematis. Tes yang dikembangkan disesuaikan dengan jenjang kemampuan tersebut. Penskoran hasil tes menggunakan panduan evaluasi yang memuat kunci dan pedoman penskoran setiap butir soal. Hasil tes yang disusun akan menjadi rancangan awal perangkat pembelajaran atau berupa draft $I$. Tes terdiri dari pre-test dan post-test.

b. Angket self-efficacy 
Setiap pernyataan angket yang disusun disesuaikan dengan kisi-kisi self-efficacy. Pernyataan yang dirancang dalam bentuk pernyataan positif dan negative. Bentuk pernyataan positif dan negative bertujuan untuk menguji kekonsistenan jawaban siswa serta memancing siswa menjawab angket sesuai dengan kebenaran yang ada pada dirinya. Hasil angket yang disusun akan menjadi rancangan awal pembelajaran atau draft $I$.

Tes disusun berdasarkan spesifikasi tujuan pembelajaran dan indikator kemampuan yang diukur. Tes yang disusun untuk mengukur kemampuan visual thinking sedangkan nontes yang di susun yaitu angket self efficacy siswa untuk melihat sikap siswa terhadap pengembangan perangkat yang di kembangkan.

\section{2) Pemilihan Format}

Hasil pemilihan format dalam penelitian ini disesuaikan dengan kurikulum KTSP. Sesuai dengan kurikulum KTSP.

1. Rencana Pelaksanaan Pembelajaran (RPP) tercantum Standar Kompetensi (SK), Kompetensi Dasar (KD), Indikator pembelajaran, tujuan pembelajaran, materi pembelajaran, kegiatan pembelajaran, penilaian dan sumber belajar, model pembelajaran, metode, alokasi waktu, tes, serta kunci jawaban dan pedoman penskorannya. Kegiatan pembelajaran terdiri dari kegiatan awal, kegiatan inti dan penutup.

2. Format Buku Siswa (BS) mengacu pada aturan BSNP (Badan Standar Nasional Pendidikan)

3. Format LAS dibuat berwarna sehingga siswa akan tertarik dan termotivasi untuk belajar. Untuk format tes kemampuan komunikasi matematis, mengacu pada indikator kemampuan komunikasi matematis

4. Format angket sikap self-efficacy siswa juga mengacu pada indikator self-efficacy. Keseluruhan komponen perangkat pembelajaran yang dirancang disesuaikan denganpembelajaran berbasis masalah agar menjadi satu kesatuan untuk kemudian diharapkan penerapannya berdampak pada peningkatan kemampuan komunikasi matematis dan self-efficacy siswa SMP Islam Terpadu Nurul 'Azizi Medan.

3) Hasil Perancangan Awal

Pada tahap ini, dihasilkan rancangan awal perangkat pembelajaran berupa Rencana Pelaksanaan Pembelajaran (RPP), Buku Guru ( BG) ,Buku Siswa (BS), dan Lembar Aktivitas Siswa (LAS) untuk 5 (lima) kali pertemuan, tes kemampuan komunikasi matematis, pedoman penskoran, kunci jawaban, serta angket selfefficacy siswa. Semua hasil tahap perancangan ini selanjutnya disebut $d r a f t$ I.

\subsection{Tahap III Pengembangan (Develop)}

Tahap pendefinisian (define) dan perancangan (design) menghasilkan rancangan awal sebuah perangkat pembelajaran yang disebut draft I. Fase pertama pada tahap pengembangan adalah melakukan validasi draft I kepada pakar/ahli (expert) kemudian dilakukan uji coba lapangan. Validasi para ahli difokuskan pada format, isi, ilustrasi, dan bahasa pada perangkat pembelajaran yang dikembangkan. Hasil validasi ahli berupa nilai validasi, koreksi, kritik, dan saran yang digunakan sebagai dasar untuk melakukan revisi dan penyempurnaan perangkat pembelajaran yang dikembangkan. Perangkat pembelajaran hasil revisi tersebut merupakan perangkat pembelajaran yang telah memenuhi kriteria valid dan selanjutnya disebut draft II.

\subsection{Tahap IV Penyebaran (Disseminate)}

Pada tahap ini, perangkat pembelajaran yang telah diujicobakan di kelas penelitian akan di uji kembali dengan membandingkan perangkat pembelajaran yang dikembangkan (kelas eksperimen) dengan perangkat yang biasa digunakan guru mata pelajaran matematika di SMP Islam Terpadu Nurul 'Azizi (kelas kontrol). Namun, tahap ini tidak dilaksanakan peneliti, dikarenakan keterbatasan waktu, biaya dan tenaga sehingga tahap ini tidak dibahas secara mendalam.

\section{HASIL PENELITIAN}

Deskripsi Peningkatan Kemampuan
Komunikasi Matematis Siswa
Menggunakan Perangkat Pembelajaran
Berdasarkan PBM yang dikembangkan
Data yang diperoleh dari hasil posttest kemampuan komunikasi matematis siswa pada uji coba I dan uji coba II dianalisis untuk mengetahui peningkatan kemampuan komunikasi matematis siswa dengan membandingkan rata-rata skor siswa yang diperoleh dari hasil posttest kemampuan komunikasi matematis siswa uji coba I dan uji coba II. Deskripsi peningkatan kemampuan komunikasi matematis siswa dengan menggunakan perangkat pembelajaran berdasarkan PBM yang dikembangkan pada uji coba I dan II ditunjukkan pada tabel

Tabel 4. Deskripsi Hasil Kemampuan Komunikasi Matematis

\begin{tabular}{ccc}
\hline Keterangan & $\begin{array}{c}\text { Posstest } \\
\text { Komunikasi } \\
\text { Matematis } \\
\text { Uji Coba I }\end{array}$ & $\begin{array}{c}\text { Posstest } \\
\text { Komunikasi } \\
\text { Matematis } \\
\text { Uji Coba II }\end{array}$ \\
\hline $\begin{array}{c}\text { Nilai } \\
\text { Tertinggi }\end{array}$ & 87,50 & 93,75 \\
\hline $\begin{array}{c}\text { Nilai } \\
\text { Terendah }\end{array}$ & 56,25 & 68,75 \\
\hline Rata-rata & 74,17 & 80,42 \\
\hline
\end{tabular}


Berdasarkan Tabel 4., hasil analisis peningkatan kemampuan komunikasi matematis siswa pada uji coba I dan uj coba II menunjukkan bahwa rata-rata komunikasi matematis siswa pada hasil posttest uji coba I adalah sebesar 74,17 meningkat menjadi 80,42 pada uji coba II. Peningkatan kemampuan matematis dilihat dari rata-rata hasil posttest uji coba I dan II dengan demikian diketahui bahwa terjadi peningkatan nilai rata-rata kemampuan komunikasi matematis siswa sebesar $8,43 \%$.

Selanjutnya, deskripsi peningkatan kemampuan komunikasi matematis siswa dengan menggunakan perangkat pembelajaran berdasarkan PBM yang dikembangkan pada uji coba I dan uji coba II untuk setiap indikator komunikasi matematis siswa dapat dilihat pada tabel berikut.

Tabel 5. Rata-rata Kemampuan Komunikasi Matematis Siswa untuk Tiap Indikator

\begin{tabular}{lcccc}
\hline \multicolumn{1}{c}{$\begin{array}{c}\text { Indikator } \\
\text { Komunikasi } \\
\text { Matematis }\end{array}$} & $\begin{array}{c}\text { Uji } \\
\text { Coba } \\
\text { I }\end{array}$ & $\begin{array}{c}\text { Uji } \\
\text { Coba } \\
\text { II }\end{array}$ & $\begin{array}{c}\text { Penin } \\
\text { gkata } \\
\text { n }\end{array}$ & \% \\
\hline $\begin{array}{l}\text { Membuat } \\
\text { dan } \\
\text { menyelidiki } \\
\text { dugaan- } \\
\text { dugaan } \\
\text { matematis }\end{array}$ & 2,50 & 2,68 & 0,18 & $\begin{array}{c}7,20 \\
\%\end{array}$ \\
\hline $\begin{array}{l}\text { Menarik } \\
\text { kesimpulan } \\
\text { dari suatu } \\
\text { argument }\end{array}$ & 2,50 & 2,6 & 0,10 & 4,00 \\
\hline $\begin{array}{l}\text { Memeriksa } \\
\text { kesahihan } \\
\text { suatu }\end{array}$ & 2,70 & 2,93 & 0,23 & 8,52 \\
argument & & & & $\%$ \\
\hline $\begin{array}{l}\text { Menemukan } \\
\text { pola pada } \\
\text { suatu gejala } \\
\text { matematis. }\end{array}$ & 1,67 & 1,97 & 0,30 & 17,96 \\
\hline & & & & $\%$ \\
\hline
\end{tabular}

Berdasarkan Tabel 5. terlihat peningkatan kemampuan komunikasi matematis siswa dari uji coba I ke uji coba II untuk setiap indikator. Pada indikator membuat dan menyelidiki dugaandugaan matematis terjadi peningkatan sebesar 7,20\%; untuk indikator menarik kesimpulan dari pernyataan terjadi peningkatan sebesar 4,00\%; untuk indikator memeriksa kesahihan suatu argumen terjadi peningkatan sebesar 8,52; dan untuk indikator menemukan pola pada suatu gejala matematisterjadi peningkatan sebesar 17,96. Untuk lebih jelasnya dapat dilihat pada Gambar 4, berikut.
Rata-rata Kemampuan Komunikasi Matematis untuk Setiap Indikator

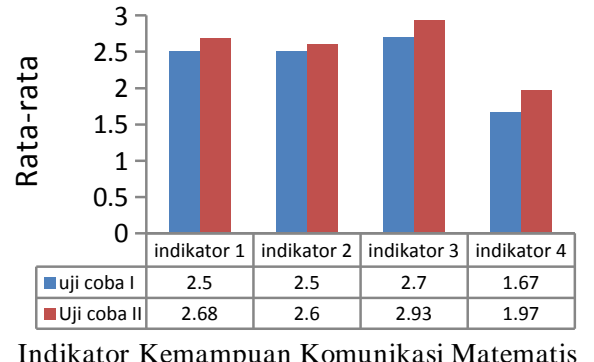

Gambar 4. Rata-rata KemampuanKomunikasi Matematis untuk Setiap Indikator

Berdasarkan table 3 dan gambar 4 di atas, dapat disimpulkan bahwa kemampuan komunikasi matematis siswa dari uji coba I ke uji coba II dilihat dari nilai rata-rata total dan nilai rata-rata setiap indikator mengalami peningkatan melalui penerapan perangkat pembelajaran berdasarkan PBM yang dikembangkan. Jadi, dapat dikatakan bahwa penggunaan perangkat pembelajaran berdasarkan PBM yang dikembangkan berdampak pada peningkatan kemampuan komunikasi matematis baik dari segi rata-rata hasil tes kemampuan komunikasi siswa maupun pada masing-masing indikator kemampuan komunikasi matematis.

\subsection{Deskripsi Peningkatan Self-Efficacy siswa setelah Penerapan Perangkat pembelajaran Berdasarkan PBM yang dikembangkan. \\ Berdasarkan hasil uji coba I dan uji coba II} diperoleh hasil angket self-efficacy siswa. Angket ini diberikan pada akhir setiap kali pertemuan yang bertujuan untuk melihat self-efficay siswa. Data yang diperoleh dari hasil angket self-efficacy uji coba I dan uji coba II dianalisis untuk mengetahui peningkatan self-efficacy siswa dengan membandingkan rata-rata skor siswa yang diperoleh dari hasil angket sikap self-efficacy uji coba I dan uji coba II. Deskripsi peningkatan selfefficacy siswa setelah penerapan perangkat pembelajaran berdasarkan PBM yang dikembangkan ditunjukkan pada Tabel 6. berikut. 
Tabel 6. Rata-rata Skor Uji Coba I dan Uji Coba II self-efficacy Siswa

\begin{tabular}{|c|c|c|c|c|}
\hline \multirow[t]{2}{*}{ No } & \multirow{2}{*}{$\begin{array}{l}\text { Indikator } \\
\text { Self- } \\
\text { Efficacy }\end{array}$} & \multicolumn{2}{|c|}{$\begin{array}{l}\text { Rata-rata per } \\
\text { Indikator }\end{array}$} & \multirow{2}{*}{$\begin{array}{l}\text { Rata- } \\
\text { rata } \\
\text { Pening } \\
\text { katan }\end{array}$} \\
\hline & & $\begin{array}{l}\text { Uji } \\
\text { Coba } \\
\text { I }\end{array}$ & $\begin{array}{c}\text { Uji } \\
\text { Coba } \\
\text { II }\end{array}$ & \\
\hline 1 & $\begin{array}{l}\text { Pengalam } \\
\text { an akan } \\
\text { kesuksesa } \\
n\end{array}$ & 16,70 & 21,20 & 4,50 \\
\hline 2 & $\begin{array}{l}\text { Pengalam } \\
\text { an } \\
\text { individu } \\
\text { lain }\end{array}$ & 13,07 & 19,70 & 6,63 \\
\hline 3 & $\begin{array}{l}\text { Pendekata } \\
\text { n sosial }\end{array}$ & 16,17 & 19,57 & 3,40 \\
\hline 4 & $\begin{array}{l}\text { Keadaan } \\
\text { fisiologis } \\
\text { dan } \\
\text { emosional }\end{array}$ & 15,73 & 19,37 & 3,64 \\
\hline \multicolumn{2}{|c|}{$\begin{array}{l}\text { Rata-rata Total } \\
\text { Semua Indikator } \\
\text { Untuk Setiap Uji } \\
\text { Coba }\end{array}$} & 61,67 & 99,77 & \\
\hline \multicolumn{4}{|c|}{$\begin{array}{l}\text { Rata-rata Total Peningkatan Semua } \\
\text { Indikator dari Uji Coba I ke Uji } \\
\text { Coba II }\end{array}$} & 38,10 \\
\hline
\end{tabular}

Untuk lebih jelasnya dapat kita lihat pada diagram berikut yang disajikan pada Gambar 4 .

Ra ta-R ata Skor Self Efficacy Siswa Untuk Setiap Indikator

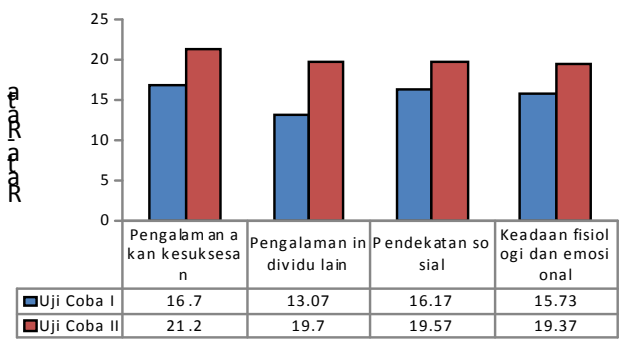

Gambar 5. Diagram Self-Efficacy Siswa Uji Coba I dan Uji Coba II

Berdasarkan Tabel 6. dan Gambar 5. di atas dapat disimpulkan bahwa secara keseluruhan ratarata hasil angket self-efficacy siswa meningkat dari hasil uji coba I ke uji coba II, yaitu pada uji coba I sebesar 61,67 sedangkan pada uji coba II sebesar 94,8 dan mengalami peningkatan sebesar 99,77. Sedangkan rata-rata skor setiap indikator juga terdapat peningkatan dari uji coba I ke uji coba II. Masing-masing rata-rata skor setiap indikator pada uji coba I yang meningkat ke uji coba II yaitu: (1) Pengalaman akan kesuksesan, dimana pada uji coba I dengan rata-rata sebesar 16,7 sedangkan pada uji coba II dengan rata-rata sebesar 21,2, mengalami peningkatan sebesar 4,50; (2) Indikator pengalaman individu lain, dimana pada uji coba I dengan rata-rata sebesar 13,07, sedangkan pada uji coba II sebesar 19,70, mengalami peningkatan sebesar 6,63; (3) Indikator pendekatan sosial, pada uji coba I dengan rata-rata sebesar 16,17 dan ratarata pada uji coba II sebesar 19,57, mengalami peningkatan sebesar 3,40; dan (4) Indikator keadaan fisiologi dan emosional, dimana rata-rata pada uji coba I sebesar 15,73, sedangkan rata-rata pada uji coba II sebesar 19,37, mengalami peningkatan sebesar 3,64.

Berdasarkan hasil di atas dapat disimpulkan bahwa self-efficacy siswa setelah penerapan perangkat pembelajaran berdasarkan PBM yang dikembangkan meningkat dari uji coba I ke uji coba II.

\subsection{Deskripsi Proses Jawaban Siswa}

Analisis proses penyelesaian jawaban siswa dalam menyelesaikan posttest kemampuan komunikasi matematis dapat dilihat berdasarkan rumusan setiap item. Analisis ini dilaksanakan untuk mengetahui kemampuan siswa memenuhi indikator kemampuan komunikasi matematis dalam penyelesaian jawaban. Berikut adalah penjabaran proses jawaban siswa.

\section{Analisis Proses Jawaban Siswa pada Tes Kemampuan Komunikasi Matematis.}

Berdasarkan lembar jawaban siswa pada tes kemampuan komunikasi matematis, berikut akan disajikan proses penyelesaian jawaban siswa untuk setiap butir soal yang dikategorikan baik, cukup dan kurang dalam aspek-aspek penalaran matematis, yaitu: (1) Menuliskan situasi atau ideide matematika ke dalam Gambar (drawing), (2) Merumuskan ide matematika ke dalam model matematika, (3) Menjelaskan secara tertulis Gambar ke dalam ide matematika; (4) Menjelaskan prosedur penyelesaian. Proses jawaban siswa pada tes kemampuan komunikasi matematis pada uji coba I dan II dianalisis secara diskriptif sebagai berikut:

Proses Jawaban Siswa pada Tes Kemampuan komunikasi Matematis pada Uji Coba I dan Uji Coba II

Proses jawaban siswa pada tes kemampuan komunikasi matematis pada uji coba I dan uji coba II dianalisis secara deskriptif sebagai berikut.

Soal nomor 1a, 1b, 2a dan $2 b$

Butir soal nomor 1a, 1b, 2a dan 2b mengukur aspek kemampuan komunikasi matematis menuliskan situasi atau ide-ide matematika ke dalam gambar. Pada aspek ini,di kelas uji coba I, hasil posttest kemampuan komunikasi matematis menunjukkan bahwa pada soal 1a dan 1b, jawaan lengkap dan benar diperoleh 19 siswa, sedangkan 
kategori cukup diperoleh 11 siswa. Pada soal 2a dan $2 \mathrm{~b}$ terdapat 12 siswa yang memuat kategori jawaban baik, sedangkan kategori cukup 17 siswa. Kemudian pada uji coba II soal 1a dan 1b yang memperoleh kategori baik adalah 24 siswa, kategori cukup 6 siswa. Sedangkan pada soal 2a dan $2 b$ terdapat 17 siswa yang memperoleh skor kategori baik dan 13 siswa pada kategori cukup.

Pada aspek menuliskan situasi atau ide-ide matematika ke dalam Gambar, proses jawaban siswa berkategori baik apabila siswa mampu memuat situasi cerita dalam soal ke bentuk gambar dengan menuliskan keterangan-keterangan angka yang lengkap pada gambar yang dibuat. Berikut ragam proses jawaban siswa pada aspek menuliskan situasi atau ide-ide matematika ke dalam Gambar yang memperoleh kategori baik pada uji coba I dan uji coba II.

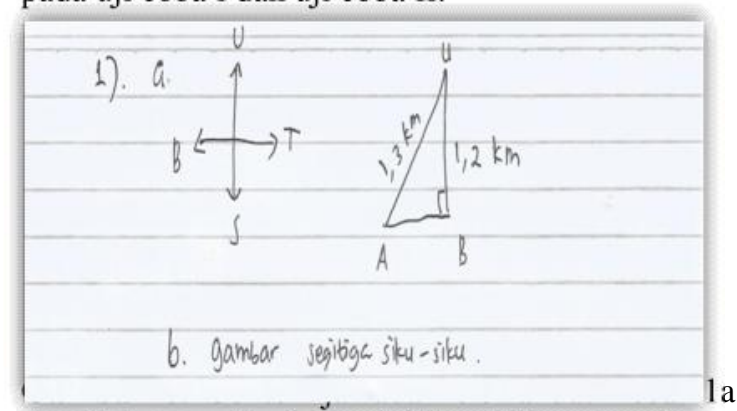

dan lb kategori baik aspek Menuliskan situasi atau ide-ide matematika ke dalam gambar uji coba I

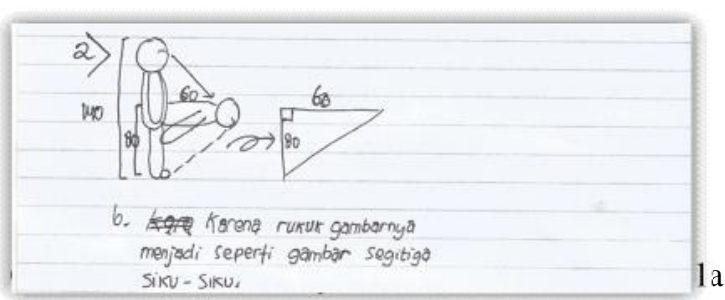

dan lb kategori baik aspek menuliskan situasi atau ide-ide matematika ke dalam gambar uji coba II

Adapun proses jawaban siswa untuk kemampuan komunikasi matematis pada uji coba I dan uji coba II selengkapnya dapat dilihat pada Tabel 7. berikut :

Tabel 7. Kriteria Penyelesaian Jawaban Siswa pada Tes Kemampuan Komunikasi Matematis Kelas Uji Coba I dan Uji Coba II

\begin{tabular}{|c|c|c|c|c|}
\hline \multirow{2}{*}{$\begin{array}{c}\text { Indikator } \\
\text { Komunikasi } \\
\text { Matematis }\end{array}$} & \multirow[t]{2}{*}{$\begin{array}{l}\text { Butir } \\
\text { Soal }\end{array}$} & \multicolumn{2}{|c|}{$\begin{array}{c}\text { Jumlah } \\
\text { Siswa } \\
\end{array}$} & \multirow[t]{2}{*}{$\begin{array}{l}\text { Kategori } \\
\text { Penilaian }\end{array}$} \\
\hline & & $\begin{array}{c}\text { Uji } \\
\text { coba } \\
\text { I }\end{array}$ & $\begin{array}{c}\text { Uji } \\
\text { coba } \\
\text { II }\end{array}$ & \\
\hline \multirow{5}{*}{$\begin{array}{l}\text { Menyatakan } \\
\text { ulang } \\
\text { sebuah } \\
\text { konsep }\end{array}$} & \multirow{3}{*}{$\begin{array}{c}1 \mathrm{a} \& \\
1 \mathrm{~b}\end{array}$} & 19 & 24 & Baik \\
\hline & & 11 & 6 & Cukup \\
\hline & & 0 & 0 & $\begin{array}{l}\text { Kurang } \\
\text { baik }\end{array}$ \\
\hline & \multirow{2}{*}{$\begin{array}{c}2 \mathrm{a} \& \\
2 \mathrm{~b}\end{array}$} & 12 & 17 & Baik \\
\hline & & 17 & 13 & Cukup \\
\hline
\end{tabular}

\begin{tabular}{cccll}
\hline & & 1 & 0 & $\begin{array}{l}\text { Kurang } \\
\text { baik }\end{array}$ \\
\cline { 2 - 5 } & 3 & 15 & 18 & Baik \\
\cline { 2 - 4 } & & 15 & 12 & Cukup \\
\hline & 0 & 0 & $\begin{array}{l}\text { Kurang } \\
\text { baik }\end{array}$ \\
\hline 4 & 18 & 14 & Baik \\
\cline { 2 - 4 } & & 9 & 9 & Cukup \\
\hline 5 & 3 & 7 & $\begin{array}{l}\text { Kurang } \\
\text { baik }\end{array}$ \\
\hline & 5 & 9 & Baik \\
\hline & 14 & 13 & Cukup \\
\hline & 12 & 8 & $\begin{array}{l}\text { Kurang } \\
\text { baik }\end{array}$ \\
\hline
\end{tabular}

Berdasarkan Tabel 7. di atas, diketahui bahwa kebanyakan siswa memperoleh kategori baik dan cukup untuk masing-masing aspek kemampuan komunikasi matematis, hanya beberapa siswa yang memperoleh nilai untuk proses jawaban yang kurang baik.

Dari deskripsi proses jawaban kemampuan komunikasi matematis siswa pada uji coba I dan II, dapat disimpulkan bahwa proses jawaban siswa pada uji coba II lebih baik dibandingkan dengan proses jawaban siswa pada uji coba I. Hal ini terlihat dari berkurangnya siswa yang memperoleh nilai 0 atau 1 dengan kategori kurang baik. Siswa lebih dominan memperoleh nilai 2 dan 3 dengan kategori cukup dan baik. Ini menandakan siswa mulai terlatih dalam menyelesaikan tes kemampuan komunikasi matematis dengan lebih sistematis mengikuti aspek-aspek kemampuan komunikasi matematis yang telah dipelajari.

\section{PEMBAHASAN}

Berdasarkan rumusan masalah dan pertanyaan penelitian yang diajukan pada bagian sebelumnya. Maka berdasarkan data yang diperoleh dari hasil uji coba I dan uji coba II akan diketahui apakah masalah dan pertanyaan penelitian yang diajukan telah terjawab atau belum. Hasil analisis data yang diperoleh dari hasil uji coba I dan II menujukkan: (1) Perangkat pembelajaran berdasarkan PBM yang dikembangkan praktis; (2) Perangkat pembelajaran berdasarkan PBM yang dikembangkan efektif; (3) adanya peningkatan kemampuan komunikasi matematis siswa melalui perangkat pembelajaran berdasarkan PBM yang dikembangkan (4) adanya peningkatan selfefficacy siswa melalui pengembangan perangkat pembelajaran berdasarkan PBM yang dikembangkan dan (5) proses jawaban siswa baik melalui perangkat pembelajaran yang dikembangkan. 


\subsection{Pengembangan Perangkat Pembelajaran Berbasis Masalah yang Praktis, dan Efektif.}

Perangkat pembelajaran yang dikembangkan dalam penelitian ini adalah perangkat pembelajaran berorientasi pembelajaran berbasis masalah. Secara umum tujuan penelitian ini adalah menghasilkan suatu produk berupa perangkat pembelajaran yang dapat meningkatkan kemampuan komunikasi matematis dan selfefficacy siswa SMP.

Pengembangan perangkat pembelajaran berbasis model pembelajaran berbasis masalah dalam penelitian ini dilakukan sesuai dengan prosedur model pengembangan Four-D. Model pengembangan Four-D terdiri dari 4 tahap yang saling berkaitan dan selalu dihubungkan dengan revisi, serta terdapat dua tahap evaluasi untuk mengasilkan suatu produk yang baik (Habeahan dan Saragih, 2015). Perangkat pembelajaran yang dikembangkan harus memiliki kualitas yang baik.

Berdasarkan hasil uji coba perangkat pembelajaran yang dilakukan di kelas VIII-A pada tahap ujicoba I, diperoleh informasi dan temuan penelitian yang menjadi dasar untuk memperbaiki perangkat pembelajaran. Hal ini dikarenakan pada tahap ujicoba I, ketuntasan hasil belajar siswa dalam pembelajaran belum mencapai kriteria yang ditentukan sehingga belum memenuhi kriteria efektif. Setelah dilakukan revisi dilanjutkan uci coba II di kelas VIII-B, diperoleh hasil bahwa perangkat pembelajaran berbasis masalah yang dikembangkan memenuhi kriteria praktis, dan efektif.

Hasil tersebut menunjukkan bahwa pengembangan perangkat pembelajaran dapat dijadikan solusi dalam memperbaiki dan menyelesaikan masalah dalam kegiatan pembelajaran. Penggunaan model pengembangan 4-D dalam penelitian ini sangat tepat karena mampu menghasilkan perangkat pembelajaran yang praktis dan efektif.

\section{KESIMPULAN}

Berdasarkan hasil analisis dan pembahasan dalam penelitian ini, dikemukakan beberapa simpulan sebagai berikut:

1. Perangkat pembelajaran berorientasi model pembelajaran berbasis masalah yang dikembangkan memenuhi kriteria valid. Validitas memenuhi criteria validitas isi dan validitas konstruk yang ditetapkan.

2. Perangkat pembelajaran berorientasi model pembelajaran berbasis masalah yang dikembangkan memenuhi criteria praktis. Kriteria kepraktisan ditinjau dari: (1) penilaian validator terhadap perangkat pembelajaran dapat digunakan dengan mudah, keterlaksanaan perangkat pembelajaran pada ujicoba II memperoleh skor rata-rata 4,11atau berada pada rentang $(4<\mathrm{P} \leq 5)$ dengan kategori sangat tinggi.

3. Perangkat pembelajaran berorientasi model pembelajaran pembelajaran berbasis masalah yang dikembangkan memenuhi criteria efektif. Kriteria efektif ditinjau dari : (1) ketuntasan hasil belajar siswa secara klasikal dengan skor minimal 75 telah tercapai $86,67 \%$ pada uji coba II; (2) aktifitas siswa pada seluruh aspek yang diamati berada toleransi waktu ideal yang ditetapkan; dan (3) respon positif siswa mencapai $86,67 \%$ terhadap komponenkomponen perangkat dan kegiatan pembelajaran.

4. Kemampuan komunikasi matematis siswa meningkat dengan sebesar $8,43 \%$ menggunakan perangkat pembelajaran berbasis masalah yang dikembangkan. Peningkatan ditinjau berdasarkan perolehan nilai post-test siswa dari ujicoba I ke ujicoba II.

5. Self-efficacy siswa meningkat dengan sebesar 38,10 atau $61,78 \%$ menggunakan perangkat pembelajaran berbasis masalah yang dikembangkan. Peningkatan ditinjau berdasarkan perolehan nilai angket self-efficacy siswa dari ujicoba I ke ujicoba II. Peningkatan self-efficacy terjadi karena terus dilatih dan dimunculkan aspek-aspeknya dalam langkahlangkah pembelajaran berbasis masalah.

6. Proses jawaban siswa pada ujicoba II lebih baik dibandingkan dengan proses jawaban siswa pada ujicoba I. Ini menandakan siswa mulai terlatih dalam menyelesaikan tes kemampuan komunikasi matematis dengan lebih sistematis mengikuti aspek-aspek kemampuan komunikasi matematis yang telah dipelajari sebelumnya.

\section{REFERENSI}

Akınoğlu, O., dkk. (2006). The Effects of Problem-Based Active Learning in Science Education on Students' Academic Achievement, Attitude and Concept learning,MarmaraÜniversitesi, Istanbul, TURKEY.

Ansari, B. I. (2012). Komunikasi Matematik dan Politik Suatu Perbandingan

KonsepdanAplikasi. Pena, Banda Aceh.

Ansari, B.I. 2009. Komunikasi Matematik. Banda Aceh: Yayasan Pena.

Ansari,B.I.(2003).Menumbuhkembangkan Kemampuan Pemahaman dan Komunikasi Matematik Siswa SMU melalui Strategi ThinkTalk-Write. Disertasi pada PPs UPI: Tidak Diterbitkan. 
Arends, Richard I. 2008. Learning to teach. Penerjemah: Drs. HellyPrajitno, M.A dan Dra.Sri Mulyantini Soetjipto.Yogyakarta: Pustaka Pelajar.

Arikunto, S. (2007). DasarDasarEvaluasiPendidikan. Jakarta: Bumi Aksara.

Arup Kundu, dkk. 2016. The Relationship Between Attitude And Self Efficacy In Mathematics Among Higher Secondary Students.Assistant Professor of Mathematics (W.B.E.S), Govt. Training College (CTE), Hooghly and Ph.D. Scholar (Ex-JRF (UGC-NET)), Department of Education, University of Calcutta,Professor (Rtd.), Department of Education, University of Calcutta, Kolkata-700027.

Aryan,B.(2007)Kemampuan Membaca dalam Pembelajaran Matematika. (online) Tersedia.

Bandura, A.(1997). Self Efficacy : The Exercise of Control. New York : W.H. Freeman and Company.

Bistari.2010. Pengembangan Kemandirian Belajar Berbasis Nilai Untuk Meningkatkan Komunikasi Matematik. Jurnal Pendidikan Matematika dan IPA Vol. 1 No. 1. Januari 2010:11-23. Diakses: J um' at, 01 M aret 2013.

Drost, J. 1993. Menjadi Pribadi Dewasa dan Mandiri. Yogyakarta: Kanisius Eko Putro.

Fachrurazi.2011. Penerapan Berbasis Masalah Untuk Meningkatkan Kemampuan Berpikir Kritis dan Komunikasi Matematis Siswa Sekolah Dasar. Edisi Khusus No.1, Agustus 2011. Diakses: Jum'at, 01 Maret 2013.

Fatokun, J.O. dan Fotakun, K.V.F. (2013). A Problem Based Learning (PBL) Application for the Teaching of Mathematics and Chemistry in Higher Schools and Tertiary Education: An Integratif Approach. Educational Research and Reviews-Academic Journal, Vol. 8.

Fauzi,A. (2011). Peningkatan Kemampuan Pemecahan Masalah dan Kemandirian Belajar Siswa Melalui Pendekatan Problem Solving. Medan: Unimed.

Furaiza, A.,Syahputra, E.,danRajagukguk, W. (2018). Differences in Metacognition and Mathematical Communication Ability Between Students Taught Using Problem Based Learning Model and Numbered Head Together Cooperative LearningModelat SMP Kartika I-2 Medan. Journal of Education and Practice, 9 (7).

Gabriel Gorghiua* ,Lumini aProblem-Based Learning - An Efficient Learning Strategy In The Science Lessons Context Gorghiuda Faculty of Electrical Engineering, Electronics and Information Technology, Valahia University Targoviste, 18-24 Unirii Blvd., 130082 Targoviste, Romania.
Hasibuan, I. S., danAmry, Z. (2017). Differences Of Students Mathematical Communication Ability Between Problems Based Learning, Realistic Mathematical Education And Inquiry Learning In SMP Negeri 1 Labuhan Deli. IOSR Journal of Research \& Method in Education, 7 (6): 54-60.

Hulukati, E. (2005). Mengembangkan Kemampuan Komunikasi dan Pemecahan Masalah Matematika Siswa SMP melalui Pembelajaran Generatif. Disertasi SPs UPI, tidak diterbitkan.

Ibrahim, M., dkk. (2000). Pembelajaran Kooperatif. Surabaya: UNESA Jakarta: Kementrian Pendidikan dan Kebudayaan Republik Indonesia.

Kementerian Pendidikan dan Kebudayaan. 2013.Matematika Kelas VII. Jakarta: Kementrian Pendidikan dan Kebudayaan Republik Indonesia.

Kementerian Pendidikan dan Kebudayaan. 2014. Matematika Kelas VII Edisi Revisi. 83.

Komariyatiningsih, Novi, dan Kesumawati, Nila. 2012. Keterkaitan Kemampuan Komunikasi matematis dengan Pendekatan Matematika. Makalah disampaikan pada Seminar Nasional Matematika dan Pendidikan Matematika FMIPA UNY pada tanggal 10 November 2012.Diakses: J um'at, $01 \mathrm{M}$ aret 2013.

LailaS.Lomibao, dkk.2016 The Influence of Mathematical Communication on Students' Mathematics Performance and Anxiety .Mindanao University of Science and Technology, Lapasan, Cagayan de Oro City, Philippines *Corresponding author: lailalomibao@gmail.com.

Meltzer, D.E. 2002.The Relationship Between Mathematics Preparation and Conceptual Learning Gain in Physics: A Possible "Hidden Variable" in Diagnostic Pretest Scores. American Journal of Physics Online]. Tersedia: http:// www. physics. iastate. edu/per/docs/AJP-Dec-2002-Vo.70-12591268.pdf.

Ming-Jang Chen.2015.Influence of Mathematical Representation and Mathematics Self- Efficacy on the Learning Effectiveness of Fifth Graders in Pattern Reasoning National Chiao Tung University No. 1001, University Rd. Hsinchu 30010, Taiwan (R.O.C).

Mustafa., Sinaga, B., dan Asmin. (2017). Development of Learning Devices Through Problem Based Learning Model to Improve Students Metacognition Ability in SMPN 17 Medan. Journal Education and Practice. 8(24), 34-41.

National Council of Teachers of Mathematics (NCTM). 2000. Principle and Standards for school mathematics. Reston, VA: NCTM. 129.

Pengembangan Perangkat Pembelajaran Matematika Berdasarkan Pembelajaran Berbasis Masalah untuk Meningkatkan Kemampuan Komunikasi dan Self-Efficacy Siswa 
NCTM. 2000. Principles and Standards for School Mathematics. USA : NCTM.

Nieven, N. 2006." Educational Design Research" dalam Educational Design Research.NewYork:Routedge.

Nur Izzati Abdullaha,*, Rohani Ahmad Tarmizia,b, RosiniAbub , The Effects of Problem Based Learning on Mathematics Performance and Affective Attributes in Learning Statistics at Form Four Secondary Level a Laboratory of Innovations in Mathematics Education, Institute for Mathematical Research, Faculty of Educational Studies Universiti Putra Malaysia.

Padmavathy, R.D danMareesh, K. (2013). Effectiveness of Problem Based Learning In Mathematics. International Multidisciplinary $e$ - Journal, 2 (1) : 45-51.

Ramdani,Yani.2012. PengembanganInstrumen Dan Bahan Ajar Untuk Meningkatkan Kemampuan Komunikasi, Penalaran, dan Koneksi Matematis Dalam Konsep Integral. Jurnal Penelitian Pendidikan Vol.13, No 1, April 2012.Diakses: Jum'at, 01 Maret 2013.

Roland G. P .2015. Importance of Mathematical Communication and Discourse in Secondary Classrooms.Cleveland State University, United States.

Reys, R. et all. (2012). Helping Children Learn Mathematics 10th Edition. John iley \& sons: USA.

Saragih,S. (2007). Mengembangkan Kemampuan Berpikir Logis dan Komunikasi Matematis Siswa SMP Melalui Pendekatan Matematika Realistik. Disertasi pada PPs UPI: Tidak Diterbitkan.

Schultz, Duane. P., Schultz, Sydney Ellen. (1990). Psychology And Industry Today (An Introduction To Industrial And Organizational Psychology 5th Edition). New York : Macmillan Publishing Company.

Scott G. Paris,Alison H. Paris. (2001). Classroom Applications of Research on Self-Regulated Learning. Educational Psychologist. 2001, Vol. 36 , No.

2 , p.89101.[Online].Tersedia:http://sohs.Pbs.uam. es/webjesus/motivev autorr/lects \% 20 extranjeras /autorre gulacion.pdf.

Sinaga,B.2007.Pengembangan Model Pembelajaran Matematika Berdasarkan Masalah Berbasis Budaya Batak ( PBMB3) . Disertasi Tidak diterbitkan. Surabaya : Program Pascasarjana UNESA.

Sudjana. 2002. Metoda Statistika. Bandung: Tarsito

Sugiyono.2008.Metode Penelitian Kuantitatif Kualitatif dan $R$ \& D.Bandung: ALFABETA.
Sugiyono. 2012. Metode Penelitian Kuantitatif, Kualitatif, dan R\&D. Bandung: Alfabeta.

Surya, E \& Syahputra, E. (2017). Improving HighLevel Thinking Skills by Development of Learning PBL Approach on the Learning Mathematics for Senior High School Students. Canadian Center of Science and Education, 10 (8): 12-20.

Surya, E., Syahputra, E., dan Juniarti. (2018). Effect of Problem Based Learning Toward Mathematical Communication Ability and Self-Regulated Learning. Journal of Education and Practice, 9 (6): 14-23.

Syahputra, E., dan Surya, E. (2014). The Development of Problem Based Learning Model to Construct High Order Thinking Skill Students' on Mathematical Learning in SMA/MA. Journal of Education and Practice, 5(39).

Thiagarajan, S; Semmel, D.S; \&Semmel, M.I. 1974. Instructional Development for Training Teachers of Exceptional Children: A Sourcebook. Indiana: Indiana University.

Trianto. (2009). Mendesain Model Pembelajaran Inovatif Progresif: Konsep, Landasan dan Impementasinya pada Kurikulum Tingkat Satuan Pendidikan ( KTSP).Jakarta: Kencana Prenada Media Group.

Trianto. (2011). Mendesain Model Pembelajaran Inovatif-Progresif: konsep, Landasan, danImplementasinyapada KTSP. Jakarta: Kencana Prenada Medi Group.

Trianto.2010. Model Pembelajaran Terpadu. Jakarta:PT. BumiAksara

Pengembangan Perangkat Pembelajaran Matematika Berdasarkan Pembelajaran Berbasis Masalah untuk Meningkatkan Kemampuan Komunikasi dan Self-Efficacy Siswa 